\title{
EDITORIAL 3
}

\section{Medicina y Derecho. Una interdependencia socio-histórica}

\author{
Raúl Viviescas-Cabrera1 ${ }^{1 D}$
}

\begin{abstract}
$T^{2}$ al vez, la primera duda que asalte al lector frente a este editorial es acerca de las conexiones que pueda tener la ciencia médica y la ciencia del derecho o la ciencia del derecho y la ciencia médica, aunque ciertamente aparentan ser sabidurías muy distantes y cada una presenta tópicos tan apartados como la responsabilidad ${ }^{1}$, las definiciones del fenómeno terrorista ${ }^{2}$ y o bacterioterapia preventiva ${ }^{3}$, existen conexiones innegables que las acercan más de lo que se sospecha.
\end{abstract}

En este sentido, a pesar de las obvias diferencias entre las dos ciencias, en sus raíces se encuentra su mayor concomitancia, ambos se ocupan del ser humano aunque desde diferentes sentidos; El Derecho aborda su semblante social y la Medicina atiende su aspecto biológico y antropológico, sigue siendo el mismo anthropos el objeto de su estudio. Así mismo, ambas ciencias humanísticas persiguen, naturalmente desde distintos enfoques, el bienestar del hombre: una como vía para alcanzar la justicia y vida en armonía, y la otra como instrumento al servicio del bienestar físico y psíquico del ser humano. Como vemos las dos ciencias están al servicio de un bienestar general, que ha permitido la preservación del hombre; por un lado fortaleciendo su desarrollo vital por medio de técnicas, instrumentos y saberes en constante perfeccionamiento y, por el otro lado, ha logrado establecerse como un ser social (Zoon politicón), autónomo y con derechos hacia su salud, a vivir en paz, con justicia y libertad, todo esto articulado por normas y principios que integran los ordenamientos jurídicos. En síntesis, la Medicina y el Derecho han sido herramientas al servicio del amparo del hombre y pilares característicos de su civilización.

Por otra parte, la relación entre estas ciencias no solo se limita a su objeto y propósito de estudio sino que además, muestran una suerte de interdependencia que nace en el seno mismo de la civilización occidental, mezclados con la religión y la magia. Entonces, pese a la distancia en los aspectos técnicos y metodológicos, el Derecho y la Medicina son conocimientos que han ido evolucionando durante milenios ciñéndose como pilastra del auge del mundo occidental. En el mismo sentido, ambas disciplinas se circundan logrando influir cada una en la otra como de la relación médico paciente se desprenden una serie de obligaciones y derechos que no solo se limita en lo ético sino que son también jurídicos; asimismo, el actuar profesional del médico se encuentra regulado por la ley, a la vez que se ve condicionado por las expectativas y demandas de sus pacientes, creando un caldo de cultivo para las ciencias del Derecho (responsabilidad medica). De la misma manera, la medicina ha permitido el desarrollo de las estructuras legales, puesto que el legislador, en algunas ocasiones, se ve en la necesidad de tomar decisiones frente a conceptos jurídicos indeterminados: como la vida, la enfermedad, la locura, la inca-

1. Universidad Sergio Arboleda. Santa Marta, Colombia. Correo: www.luar26@gmail.com - http://orcid.org/0000-0002-8691-0755 
pacidad o la capacidad aspectos que aunque son importantes establecer para el Derecho requieren de la precisión del concepto médico.

Para concluir, quiero señalar que el desarrollo de las ciencias médicas y de las ciencias del Derecho son los avances de la humanidad hacia un mayor bienestar general, y su interdependencia debe seguir apuntando a un desarrollo integral de ambas disciplinas guiadas por la batuta de la investigación científica que les permita envolverse con las diferentes ramas del saber, y rompa con la endogamia académica que cercena e impide el avance y el hallazgo de las soluciones adecuadas en un mundo cada vez más complejo.

\section{DECLARACIÓN SOBRE CONFLICTOS DE INTERESES}

Ninguno que declarar

\section{REFERENCIAS BIBLIOGRÁFICAS}

1. Cuenca-Tovar R, Beltrán-Ramírez J. ¿La responsabilidad objetiva cumple con los fines de la responsabilidad patrimonial de la administración pública en Colombia y España? Vis Iuris. Revista De Derecho Y Ciencias Sociales. 2015; 2(3): 69-83. Disponible en: https://revistas. usergioarboleda.edu.co/index.php/visiuris/ article/view/950

2. Mendoza-Perdomo J. El fenómeno terrorista y su lógica de indefinición. Vis Iuris. Revista De Derecho Y Ciencias Sociales. 2017; 1(2): 45-58. Disponible en: https://revistas.usergioarboleda. edu.co/index.php/visiuris/article/view/657

3. Llorens-Folgado S, Fernández-Rius A. Bacterioterapia preventiva de la obesidad en la comunidad de los indios Pima: evidencias científicas. Duazary. 2017; 14(2): 188-196. 